\title{
Review and Discussion of The Co(te)lette Film:
}

\section{Dir. Mike Figgis / Chor. Ann Van den Broek}

\author{
Priscilla Guy
}

\section{Background / Context}

In 2010, English director Mike Figgis presented The Co(te)lette Film, a cinematographic adaptation of eponymous live performance by Dutch choreographer Ann Van den Broek, Co(te)lette (2007). At the beginning of the film, the camera shows three women on all fours at the centre of a large podium. From the very first shots, the viewer is given exquisite high definitions images and close ups of these gorgeous women and their more intimate body parts as they move frenetically and breath heavily. The synopsis of the film states: "There is no confrontation, nor rivalry. No story-telling, no solution and no ending. [The three women] grapple with the meaning and physical translation of beauty and perishability, rawness and fragility. The dancers are slaves of their own desires while trying to get in control of them."

The live version of this piece was a great success on international stages, touring in Europe and America. In a Q\&A after a recent show in Montreal, Canada, ${ }^{2}$ choreographer Ann Van den Broek remained vague with regard to her collaboration with Figgis for the film adaptation of her work, mentioning mostly her initial fear of seeing her choreography "stolen" by the voracious camera. She shared amusing anecdotes about their artistic disagreements, yet said very little on Figgis' adaptation of her work. Talking mostly about her own creative process with the dancers, she cautiously navigated audience members' questions on the feminist themes at play in the live version of the piece and their translation to the screen. Leaving interpretations open, she invited spectators to question those aspects of the film they found challenging. Although her personal response to Figgis' film remained ambiguous, she also acknowledged the great exposure the piece received after the release of The Co(te)lette Film, and considers it an important, valuable work in the art field.

Although the film has received a fair amount of attention from artists and critics in the film and dance milieus, its most controversial aspects have received virtually no systematic evaluation, and beg further investigation and in-depth discussion in light of its gendered representation of female bodies. As noted by artist and scholar Douglas Rosenberg:

This film (as well as others with similar screen politics) has gone largely unexamined and without the kind of critique that every college student that has ever taken a contemporary art course let alone a Women's or Gender Studies course is trained to do. [...] The fetishization of dancing bodies is common in this milieu, made more so by the uncritical viewing practices that are the norm in festivals and distribution systems. ${ }^{3}$ 
Indeed, most critics celebrate the audacity and radicalism of the film, and applaud images of crude violence, hyper sexualisation, misogyny, slavery and dysfunctional femininity. Under these circumstances, the question must be asked: is the celebration of such images in itself an artistic tour de force, or is it rather a perfectly orchestrated marketing strategy reproducing precisely what the original choreography sought to challenge? Rather than offering a formal critique of this work of art, analyzing its implications in a discussion of mediated female bodies, and questioning its beautifully directed yet sensationalist images, most critics seem to welcome the film as a relevant feminist object. ${ }^{4}$ The fact that many of its formal/artistic/technical components contradict Van den Broek's initial feminist claim remains absent of the critical landscape.

This essay comprises two parts: (1) a presentation-anchored in previous reviews of the film-addressing both the film's cinematographic and choreographic elements and the disciplinary crossings between dance and cinema, as well as the transformation of the viewer's gaze from live performance to screendance; and (2) an open, rigorous discussion of Figgis' cinematographic strategies and dramaturgic choices in relation to specific types of body representation and gendered approach to performativity. Using Erin Brannigan's writing on kinaesthetic empathy in musicals, ${ }^{5}$ I question Figgis' representation of the female persona and its implications in the context of his film. Furthermore, building on British feminist film theorist Laura Mulvey's essay "Visual Pleasure and Narrative Cinema" (1975), I highlight aspects of Figgis' film that transform Van den Broek's choreographic material and reinforce stereotyped representations of women on screen. Discussing The Co(te)lette Film in terms of artistic/technical merit, I also put forward a critical analysis of the implications of such contemporary screendance practices in relation to the representation of women on screen. This essay thus aims to create space to problematize some of the most pressing issues raised by the film, rather than simply observing le spectacle of reiterated clichés in our hybrid field.

\section{Part One: Review}

The Co(te)lette Film | Mike Figgis, 2010, United Kingdom, 60 min.

"[A true work of art] does not merely describe something of which we are already fully aware. This new reality consists of elements selected from natural reality and is achieved through the establishment of a new, imaginative relationship between these elements and the natural world."

- Maya Deren

Three women are exposed at the centre of a large podium, in a vast loft: neon lights, cold set up and crude ambiance are at play. The camera brings the viewer closer to their bodies, furrowing their face, legs and crotch, while they perform a very tight, sharp and synchronized pelvis movement, breathing loudly, rhythmically. Around them, down from the podium in a softer light, a crowd of men and women, richly 
dressed, some of them leaning on high bars with a drink. The ambiance evokes a strip club or a bar. The camera sometimes zooms out in a way that allows the viewer to embrace the scene completely: the podium, the three women and the crowd of voyeurs looking at them, silently, whispering at times. The music completes the portrait: lounge music, beat, techno. Embodying stereotypes of beauty, sensuality, perversion and sexual slavery, the three women perform a one-hour marathon of walks, codified gestures, exacerbated facial expressions, and hysterical climaxes through rhythm and repetition.

While The Co(te)lette Film has undeniable artistic qualities (a very meticulous artistic direction, a quite impressive sound score and use of breath, a tremendously seductive image quality) and the impressive choreography inevitably moves us at times, the artistic synergy that we might expect from the collaboration between such an experienced filmmaker and choreographer is not at play. In spite of Figgis' strategies for transporting the choreography to the screen (360 degree filming, closeups, finely orchestrated mise en scène, and use of a steadycam for some segments), the connection between dance and cinema remains tenuous. Rather than using the cinematic potential of Van den Broek's complex choreographic material to propel the piece on screen and reveal a singular version of it, Figgis' adaptation privileges a sensationalist gaze on the choreography, which is a far easier track to go down. The filmmaker makes important choices that alter Van den Broek's choreographic work, including the addition of the crowd around the podium on which the dancers evolve, instead of a traditional stage with wings, and the close-ups on genitals and other body parts which we would not see in a live performance in a theatre. These choices shift the focus of the spectator and dictate not only where to look, but also how to look. What was raw in Van den Broek's dramaturgy becomes graphic under Figgis' aesthetic. That certainly counts in the promotion of the film and its great popularity, giving it a pornographic edge that raises curiosity and gathers audience members from way beyond the dance world. At this juncture, the gap separating the live performance and the film is wide: if everything was at stake for both spectators and dancers on stage, everything seems already determined for the three performers on screen. Potentially inventive interactions between movement, camera, and editing are upstaged by a tacky, seductive, and commercial aesthetic.

Although overall the piece fails to convince at the level of the synergy between movement and camera, some scenes achieve such a symbiotic relationship. For example, the scene in which two dancers manipulate a third one, completely naked, hitting her body against the floor in an impressive and highly precise choreographic sequence, is quite interesting. The dancer's arms and legs seem disarticulated while she is completely at the mercy of her colleagues. Skin slaps, limbs hit the floor. Here, Figgis uses the cinematic potential of the choreographic material: the close-ups offer the viewer surprising points of view of these manipulations and highlight the contrasts between hyper-organized brutality and shocking gestures. These images show bruises, red skin and vulnerable flesh, and generate a highly physical response for the viewer. In terms of sound, this scene is wisely explored as we hear the impact of 
the body on the floor much louder than we would in a live performance setting, increasing the tension at this point in the film. Sounds of breathing, hits, falls and slaps are amplified and give the whole a surreal feel. The precision of the choreography is the turning point of this scene, which offers a powerful, even mysterious balance between raw and violent behaviour and precise and virtuosic manipulation. Dance and cinema complete each other and propel the initial choreographic material further on screen.

Other scenes offer similar interesting effects by hybridizing movement of the body, of the camera, and of editing, such as the scene of the "rave party" where the use of stroboscopic light, excessive breathing, fast editing, and camera movement contribute to a dramatic construction through a superimposition of choreographic and cinematic strategies. But apart from those scenes and some provocative segments, one must ask: How are hyper-sexuality, violence, sexism, the balance of power, and femininity treated in this cinematographic adaptation? How is the work of Van den Broek reinvented in such setting? And what does the screen offer to the initial artistic vision behind this work?

In press conference after the screening at Cinédanse Montréal in 2012, Figgis mentioned that some choreographers are afraid that their work will be "stolen" by the director, the camera, or the film technique. While Figgis' film maintains the original chronology of the choreography, the camera does invade the podium where the performers evolve, a shameless voyeur-even predator in some sections-amongst them, crawling next to one of the dancers or seemingly trying to catch the most interesting angle on her body by following her. The choreography does not mould to the site of the screen: rather the camera consumes both movement and bodies. Van den Broek's choreography moves from subject to object, and so do the women in her work. More than an adaptation of Van den Broek's work, Figgis' film offers a totally opposite perspective on the thematic explored by the choreographer, which is significant given that the work is presented as an adaptation for the screen, not a freereinterpretation.

Let me now discuss the transition of this piece from stage to screen in order to highlight how such a transition led to the reiteration of clichés and stereotyped representations of women and their bodies, instead of generating real discussions about these issues and pushing forward the medium of screendance. As a matter of fact, the absence of discussion about how and why this subject is brought to the screen evacuates deeper analysis and debates that could be deployed around this film. Most reviews articulate what is being presented, which is only one part of the exercise.

\section{Part Two: Discussion}

The site

One of the most crucial elements that deflects Van den Broek' work when transferred to the screen is the use of the site-that is, the screen as a site. As I already 
mentioned, the actual choreographic work (movement sequences and chronology) remains quite intact in the transition from stage to screen, which could lead us to think that the work and its meaning are intact, too. As any serious choreographer would admit, however, movement sequences are only one aspect of choreography. Other elements such as the context and site of presentation come into play to give it its complete signification as an art piece.

Van den Broek uses the stage as a site to challenge some stereotypes, preconceived ideas, and socially accepted images of women. She puts in a theatre what we see every day on the Internet, in advertisements, on television, and in magazines. As a result, she creates a tension by asking three dancers to embody various roles, behaviours and body attitudes, as well as physical and mental states that mirror reality. She takes what we most often see on screens (films, television, publicity) and reproduces that social material in a theatre.

Live performance engages audiences in a specific way: the actual presence of human beings on stage challenges the public and initiates a connection between them and the artists. The site shapes the material and greatly influences the way the audience encounters the choreographic material. The proximity with the spectators, or at least their presence in the same room, is crucial in the development of the work on stage. The screen as a site is radically different from the stage. Douglas Rosenberg writes about the site-specificity of screendance:

... screendance culture is an expanded culture, a site-specific practice that, if true to form, moves beyond the simple migration of dance from the stage (with the inherent motivations and logic of dance intact) and re-sites bodies in motion in a filmic or screenic space. Such spaces have specificity that is often at odds with choreographic logic, which had been conceptualized in actual three-dimensional space. ${ }^{6}$

In the live version of Co(te)lette, the audience is seated in front of the stage, while the sides and the back of the stage are delimited by a thin white curtain that goes from ceiling to the floor. The three dancers occupy that space, in which they are "safe" and from which they can escape at any moment; in fact, one of them hides her head under the curtain at some point, while at other moments the dancers simply face one of those curtains, hiding their faces from our gaze. The theatre provides both dancers and spectators with a frame from which they share a question, a drama, an intrigue. The audience is sitting while the dancers are moving all over the place. The balance of power is in their favor: they control the room, they travel around, they know what is next and the spectators do not. The site allows them liberties, while it keeps the audience "captive" of their seats. Our gaze is directed by various choreographic strategies: sometimes intentionally busy and confused, the work on stage forces us to choose what to look at; sometimes very clearly pointed at one event on stage, our gaze is guided; sometimes caught by a detail, a piece of clothing, or a shoe, our gaze reframes the work with our personal fantasies and interests. 
This is, partly, how Co(te)lette denunciates certain stereotypes: by making them visible, on stage, with no shame and no censure, without giving the answer or the solution to the audience, letting them find their own path through the proposed work. By asking the audience to watch these women, broken, courageous, lost, fierce, and tired, Van den Broek exposes this multifaceted female persona through the site of the theatre and from the perspective of the spectator in her or his seat. Audience and artists share a common time and space for the whole show, from which questions emerge. This duality and the physical presence of both groups (public/dancers) is crucial to the realization of Van den Broek's choreographic goals. The dancers break the fourth wall and challenge the spectators; they perform a highly physical marathon that the public can feel, hear, and observe in real time. Their physical exhaustion, their craziness, and their aggressiveness is palpable, and therefore meaningful in the context of this piece.

Figgis, meanwhile, takes a work that addresses certain questions about the female body, related notably to hyper-sexualization, pressure, and vulnerability, and puts it on screen, which is the perfect site for easy and free consumption of the female body. While Van den Broek performs a critique of this pressure on women by presenting such bodies through multiple physical/mental states in a theatre, Figgis' adaptation fails to move beyond Van den Broek's point of departure, with the result that the former ends up reproducing precisely what the latter seeks to problematize. Figgis' film borrows deliberately from popular references such as soft pornography and the over-eroticized and graphic representations of bodies in advertisement. Objectified women on screen is nothing new or shocking; it is what we are used to seeing on the various screens that surround us. With the use of the cinematic apparatus, Figgis narrows the multiplicity of embodied states to a common and familiar spectrum, to a point where the fine line between the criticism and the simple reiteration is completely blurred. What you see is what you get.

Without suggesting that the adaption of Co(te)lette for the screen is an impossible or impertinent project to accomplish, the motivations behind it can nevertheless be seriously questioned. While feminists concerns about the representation of women in the media must be addressed from various angles, The Co(te)lette Film is more of a seductive product that regurgitates reality without digging any further the challenges it entails. When attending the live performance in Montreal, l, to the contrary, saw a work that had much more depth than the film. I saw women pushing their physical limits, I heard them yelling at us, the public, and I felt sorry for, as much as I felt impressed by, their characters. Putting such choreographic material on screen should come with careful attention to the implications of the screen as a site to conserve its specific artistic and social concerns. It is crucial to keep in mind that documenting a piece and adapting it for the screen are two very different projects, and that the latter asks us to build a new hybrid language in order to recreate movement material for the eye of the camera and for the screen as a site. 


\section{Agency and kinaesthetic empathy}

In the live version of Co(te)lette, dancers go from hyper-codified movements to emotional states, from very directional attitudes toward the audience to vulnerable postures. They repeat this cycle several times and, in the process, they communicate the multiplicity of their states to the public. They get close to the first row of seats; sometimes they even touch audience members. They challenge the public, look at them, and walk towards them. They show the audience their vulnerability, their craziness, their despair, their slavery. But ultimately, the dancers are the ones who decide when to stop this cycle. The audience members have no control over what is happening on stage, yet it is somehow happening to them as well, as they share the room with the three dancers. The rhythms of the walks and movements travel from stage to audience. The spectators are ultimately physically engaged with the protagonists: they see each other and experience duration together, increasing the kinaesthetic empathy of the spectator. Such empathy is present as well in cinema, as explained by Karen Pearlman in her writing on editing:

Kinesthetic empathy is feeling with movement, a sensitivity we have developed by perceiving and being movement and a sensitivity that, I propose, is particularly relevant to editors of moving pictures. Neurophysiologist Arnold Modell describes the activation of kinesthetic empathy by saying, "The perception of feelings relies on the corporeal imagination, which in turn is determined by the history of the self." I am drawn to this phrase "corporeal imagination," which suggests that the body not only thinks, it imagines, in this case imagining how another body feels. And it imagines in relation to its own experience, drawing on remembered sensation to recognize feeling in movement. ${ }^{7}$

Pearlman builds on Modell's observations regarding the work of film editor and how working with moving images can be as kinaesthetic as working with actual bodies in space. Erin Brannigan also describes the phenomenon of kinaesthetic empathy in films in her chapter on musicals. Writing about key characteristics of famous female film stars such as Marilyn Monroe and Ginger Rogers, she explains that "It is this human potential for physical vigour, power, energy, and force beyond the utilitarian, exemplified in the performance of the musical star, that the spectator intuitively recognizes or feel. The excess somatic energy in such performances transfers kinetically to the audience through an affective force." ${ }^{8}$

Clearly, kinaesthetic empathy is at play in The Co(te)lette Film. Because of the formal elements proper to the film and the way it was shot and edited, however, this kinetic relation between performers and spectators is completely different from what Van den Broek had established and interferes with the initial feminist thematic. In the film, the choreography happens on a podium with a group of voyeurs crowded around the three dancers, captured by a camera, consumed by the viewer of the film. The kinetic charge received by the spectator in the live performance of Co(te)lette is completely altered by the addition of those voyeurs and by putting the spectator in a 
retracted position. The viewer looks at the scene through the lens and happens to be a third witness after the camera and the people crowded around the podium. Combined with the fact that the camera invades the dancer's space, the balance of power that was so efficient in the live performance is completely reversed. The three women cannot escape this situation and fall under the many gazes starring at them. They do not have anywhere to go or hide. No back wall, no curtain. The voyeurs are all around them instead of on one side of the stage, which makes them even more captive. In the live performance, they seem captive of their own obsessions, while on film they are captive of the frame, of the podium, of the people witnessing their crisis, of the camera tracking them. The spectators see their gaze being directed to very specific points in space and specific body parts. A decidedly male gaze eroticizes the choreographic material and propels Figgis' camera. It forces our eye to follow a crotch, it offers close-ups on genitals or breasts, and it shows open mouths, open rib cage and chest breathing fast. The film flattens Van den Broek's multilayered female persona and reduces it to an object of desire.

In her now famous essay Visual Pleasure and Narrative Cinema (1975), ${ }^{9}$ British feminist film theorist Laura Mulvey articulates an incisive critique of the representation of women in the Hollywood cinema of the 1930s, 1940s and 1950s. What she addresses in this manifesto is illuminating for our discussion, as she describes a male gaze that dominates the form, and a "silent image of woman" that becomes only a receptacle for the spectator's fantasies: "The beauty of the woman as object and the screen space coalesce; she is no longer the bearer of guilt but a perfect product, whose body, stylised and fragmented by close-ups, is the content of the film and the direct recipient of the spectator's look."10 In Figgis' film, the spectator is not connected anymore to the three performers, but isolated in its own fantasies, guided by graphic and stylistic strategies. The kinaesthetic empathy from the stage version is lost to the profit of physical excitement, arousal, or malaise. As Mulvey points out, women in such films become simple objects of contemplation and/or products of consumptionpassive and plain surfaces on which (male) fantasies take form. Spectators definitely traverse a variety of emotions during The Co(te)lette Film and they do experience some sort of kinaesthetic empathy under such dynamic-editing plays an important role in this matter, as it is fast and disorienting at times, reminding us of music video or publicity in which the female body is often objectified. Thus, the result echoes socially constructed and commercially reiterated types of visual pleasure associated with the female body, and puts the viewer in a familiar position as opposed to engaging him or her in a kinetic tension-and potentially a critical discussion-in response to such images. The spectator is disengaged from the kinetic charge present in the live version of the work and does not share the struggle of the performers: he or she rather witnesses the scenes through the eye of the camera.

In The Co(te)lette Film, the dancers' agency is reduced to zero, while in the live performance the three women perform a fantastic and ecstatic embodiment of all sorts of clichés, with powerful interaction with the spectators. While Van den Broek gives her dancers and the audience a challenging experience to share, in which the 
female body is being pushed, deconstructed, and exposed without judgment or censure, Figgis reduces this challenge to the witnessing of three women's vulnerability, powerlessness, and hysteria, under the gaze of a voracious camera. To be sure, neither the original choreography nor Figgis' adaptation propose solutions to or judgmental statements about issues pertaining to women's reality in contemporary society. Van den Broek insists on letting her work remain open to interpretations, preferring to present a multifaceted representation of women and avoiding any commentary on it. Yet, she offers an open discussion in which dancing women participate with their strengths and fears, within the limits that are imposed on them, yet constantly pushing against those limits. In contrast, Figgis closes the circle around the women/dancers and makes them objects of consumption.

\section{Conclusion}

In conclusion, the strength of the original choreographic work is not only being undermined by The Co(te)lette Film, but also completely deflected by its transposition on screen. Not all books make good movies. Not all performances are meant to be adapted for the world of cinema and screens. And if they are, it is worth questioning the implications of such transpositions and the motivations behind them. In The Co(te)lette Film, the screen as a site and the way it is used reaffirms endless myths and contradicts feminist themes explored in the original performance. The film, and the way it was directed/edited, offers another occasion to see women depicted as victims or objects: they may well be captive of their own desires, yet under Figgis' vision they are mostly captive of cinema's fantasies.

Screendance needs challenging works, debates and criticism, but it also needs works that carry responsible visions and strong discourses on dancing bodies in order to facilitate its ascension as an art form in its own right. While the representation of women has been the object of several manipulations in the public sphere, screendance represents an important vehicle to challenge, deconstruct, and critically reflect upon them. In 1975, Mulvey called for an alternative approach to cinema in which visual pleasure is destroyed to the benefit of "a new language of desire":

The alternative cinema provides a space for a cinema to be born which is radical in both a political and an aesthetic sense and challenges the basic assumptions of the mainstream film. This is not to reject the latter moralistically, but to highlight the ways in which its formal preoccupations reflect the psychical obsessions of the society which produced it, and, further, to stress that the alternative cinema must start specifically by reacting against these obsessions and assumptions. A politically and aesthetically avant-garde cinema is now possible, but it can still only exist as a counterpoint.... The alternative is the thrill that comes from leaving the past behind without rejecting it, transcending outworn or oppressive forms, or daring to break with normal pleasurable expectations. ${ }^{11}$ 
With the increasing accessibility of screendance through digital development and the presence of screens everywhere, this hybrid form could be the perfect counterpoint to mediocre images of the female body. By revealing the power of human body on screen, as opposed to reiterating it as an object/product of consumption, screendance has tremendous potential for feminist artists. In my opinion, that Figgis' film was labeled shocking, radical, or revolutionary does not make any sense. Radical works are not simply made of tacky re-collections of controversial images. The problem with The Co(te)lette Film is certainly not the fact that it is provocative and edgy, or that it shows nudity, sexuality, or violence: many controversial artists have challenged representations of the human body on stage, on screen, or in public spaces and museums, pushing further the limits of what is acceptable and what people are ready to see or not. ${ }^{12}$ But radical artworks also entail a novel and unpredictable way to depict a reality, drawing from the natural world (as Maya Deren says) and expressing that reality with boldness, against what is expected. Radicalism in the arts is not an aesthetic or a style: it is an attitude towards creation and a desire to see the world change.

\section{Notes}

1. "Essential Dance Film - The Co(te)lette Film (Trailer)," Tendu.TV, YouTube video, https://www.youtube.com/watch?v=gu2r3P04DnA.

2. Co(te)lette, presented at Usine C, November 19-21, 2013.

3. Douglas Rosenberg, "Re: More Territories for the Co(te)lette Film." Centre for Screendance, May 9, 2012, http://screendance.wordpress.com/2012/05/09/re-moreterritories-for-the-cotelette-film/.

4. See the following Huffington Post reviews of The Co(te)lette Film: Jennifer Edwards, "Embodied Women as Window on Feminism: The Co(te)lette Film Served Up on Your Lap[top]," April 23, 2012, http://www.huffingtonpost.com/jenniferedwards/embodied-women-as-window-_b_1446147.html; Jean-François Cyr, "«The Co(te) lette film» de Mike Figgis au festival Cinédanse: la charge émotive des corps," September 21, 2012, http://quebec.huffingtonpost.ca/2012/09/21/the-cote-lette-filmmike-figgis_n_1903129.html; and Lisa Paul Streitfeld, "(R)evolution: 'The Co(te)lette Film' And the Death of Sex," September 5, 2012, http://www.huffingtonpost.com/lisapaul-streitfeld/mike-figgis-revolutionary_b_1855699.html.

5. Erin Brannigan, Dancefilm: Choreography and the Moving Image (New York: Oxford University Press, 2011).

6. Douglas Rosenberg, Screendance: Inscribing the Ephemeral Image (New York: Oxford University Press, 2012), 155.

7. Karen Pearlman, Cutting Rhythms: Shaping the Film Edit (USA: Focal Press, 2009), 10. 
8. Brannigan, Dancefilm, 153.

9. Laura Mulvey, Visual Pleasure and Narrative Cinema, Screen 16, no. 3 (Autumn 1975), 6-18. http://www.jahsonic.com/VPNC.html.

10. Ibid., 7.

11. Ibid., 2.

12. See works from Marina Abramovic, Romeo Castellucci, and Dave St-Pierre for radical artistic approaches.

\section{References}

Brannigan, Erin. Dancefilm: Choreography and the Moving Image. New York: Oxford University Press, 2011.

Co(te)lette. Presented at Usine C. November 19-21, 2013.

Cyr, Jean-François "«The Co(te) lette film» de Mike Figgis au festival Cinédanse: la charge émotive des corps." Le Huffington Post: Québec, September 21, 2012, http://quebec.huffingtonpost.ca/2012/09/21/the-cote-lette-film-mikefiggis_n_1903129.html.

Edwards, Jennifer. "Embodied Women as Window on Feminism: The Co(te)lette Film Served Up on Your Lap[top]." Huffington Post, April 23, 2012.

http://www.huffingtonpost.com/jennifer-edwards/embodied-women-as-window_b_1446147.html.

"Essential Dance Film - The Co(te)lette Film (Trailer)." Tendu.TV, YouTube video, https://www.youtube.com/watch?v=gu2r3P04DnA.

Mulvey, Laura. Visual Pleasure and Narrative Cinema. Screen 16, no. 3 (Autumn 1975): 6-18. http://www.jahsonic.com/VPNC.html.

Pearlman, Karen. Cutting Rhythms: Shaping the Film Edit. USA: Focal Press, 2009.

Rosenberg, Douglas. "Re: More Territories for the Co(te)lette Film." Centre for Screendance, May 9, 2012. http://screendance.wordpress.com/2012/05/09/re-moreterritories-for-the-cotelette-film/.

Streitfeld, Lisa Paul. "(R)evolution: 'The Co(te)lette Film' And the Death of Sex." Huffington Post, September 5, 2012. http://www.huffingtonpost.com/lisa-paulstreitfeld/mike-figgis-revolutionary_b_1855699.html. 